\title{
Shifting alliances in accessing the underground
}

\author{
Sabine Luning and Robert Jan Pijpers
}

Since 2011, when research for our article 'Governing access to gold in Ghana: indepth geopolitics on mining concessions' (Luning and Pijpers 2017) was conducted, the dynamics of gold mining in Ghana have changed significantly. In 2017, a new president was elected who swiftly initiated a 'war on galamsey', supported by media and civil society groups, and the past years have witnessed a steep increase in the Chinese presence in and around the mining sector (in mining itself, but also in providing equipment). Almost inevitably, research output based on fieldwork is not in sync with social developments at the time of publication. Yet, the recent developments strongly resonate with two preoccupations of our article: (1) the relationship between politics and mining in terms of hybrid governance; and (2) the effects of differentiation in technological capacities on cohabitation arrangements. An important reason for organizing a debate section around our article is the turbulent developments that have occurred around mining in Ghana since our fieldwork. We asked several experts to discuss our article in the light of the recent developments. What do these current trends mean for our analysis? And is it still helpful in explaining the new developments?

Longer temporal perspectives are important. The contribution by Samuel Ntewusu supports some of our viewpoints from a historical perspective. His analysis illustrates longer-term dimensions of the connection between politics and mining, including miners' dependencies on chiefs in order to gain access to mining sites. He describes transformations in these connections, in particular those resulting from the interest that the colonial administration developed in mining. Prerogatives of chiefs were seriously menaced by the colonial state's attempts to gain sovereignty in attributing mining titles, and by the almost exclusive allocation of these titles to foreign industrial mining companies. With this historical perspective in mind, the ways in which chiefs currently try to dominate small-scale mining, as seen in our article, can be seen as attempts to regain terrain they lost in earlier times. Their influence in organizing galamsey who do not have formal mining titles should be understood in relation to this longer history, in which their political authority was marginalized by the colonial state. Ntewusu's historical analysis shows the importance of understanding mining practices - their scale and (lack of) formalization - as informed by dynamics within the field of hybrid governance (cf. Geenen 2016; Hardin 2011). Relations between the state and customary authorities are key to understanding the room for manoeuvre, or lack thereof, of small-scale miners in the past and in the

\footnotetext{
Sabine Luning is a senior lecturer at the Institute of Cultural Anthropology and Development Sociology, Leiden University. Her research focuses on economic anthropology, in particular relations between large-scale and small-scale goldmining, and state-company-community relations in West Africa. Email: sluning@fsw.leidenuniv.nl

Robert Jan Pijpers is a postdoctoral researcher at the Institute of Social and Cultural Anthropology, University of Hamburg. His work focuses on land use and governance, social and economic change, and the micro-politics of resource extraction in West Africa. Email: robert.pijpers@uni-hamburg.de
} 
present. Currently, the dynamics in hybrid governance are influenced by electoral processes. Our quote about miners representing 10,000 votes is given a temporal boom-and-bust dimension in Ntewusu's commentary: he shows how, today and in the past, the government's approach to galamsey has been characterized by an intensification of policing at the start of a new presidential period and its waning closer to elections.

Ntewusu's commentary thus allows us to place our analysis of in-depth geopolitics in a broader temporal perspective, particularly with regard to the dynamics between politics and mining. How can we extend this attention to temporal processes to explain some of the other developments that have emerged since 2011 ? Crawford and Botchwey argue that the cohabitation arrangements described in our article are lessening in importance, and they do not expect them to last in the course of the current developments. Their assessment is based on two trends: (1) the world of mining is so strongly marked by the mobility of miners that autochthony claims are becoming untenable; and (2) the scaling up of technologies in artisanal and small-scale mining as a result of Chinese involvement will undermine the arrangements between artisanal and small-scale mining and large-scale mining identified in our article. Autochthony claims may, however, be pertinent in the context of mining, precisely because mobility is a key feature. Miners do indeed often come from elsewhere but they arrive in social settings with particular authority structures and forms of land use in place. Those who are positioned as potential hosts - not so much the miners themselves will be keen to play the autochthony card. First of all, chiefs and local landowners will position themselves as authorities belonging to the places miners try to access. Moreover, local inhabitants may seek to protect their livelihoods and residential arrangements using claims in terms of temporal precedence, and certain groups of miners may try to capitalize on claims that their arrival preceded that of other groups or forms of mining. These processes of intensifying claims in autochthony, or broader identity politics, in times of increased mobility have been convincingly described by various authors (Geschiere and Nyamnjoh 2000; Geschiere 2009; Ceuppens and Geschiere 2005; Eriksen 2005; Eriksen and Schober 2016; Lanzano 2018; Pijpers 2018; Luning 2018). They show that processes of rapid change, including those taking place within neoliberal developments, may ignite and further strengthen claims to originary belonging.

These dynamics, too, need to be studied over longer periods of time (see, for example, D'Angelo and Pijpers 2018). At the start of a mining boom, for instance, autochthony claims may appear weak, but they may well intensify at a later stage. Similarly, claims based on autochthony can seem quite plausible and legitimate at one moment, only to be superseded in the next. This is precisely what Crawford and Botchwey anticipate for the Keegan and Newmont cases in our article; under the influence of Chinese scaling up of mining operations, they predict changes in the cohabitation arrangements we describe between artisanal and small-scale mining and large-scale mining actors. The technologies that Chinese investors and experts can supply to small-scale miners may come to undermine - literally - arrangements based on distinctive access to ore bodies. Largescale mining actors will have to block miners who, with Chinese backing, would be able to access considerably more ore than before. This is a plausible future scenario that, in fact, endorses our analysis. Potentially, up-scaled technologies will encourage artisanal miners to compete more fiercely with large-scale miners. 
How this plays out in forms of cohabitation will continue to depend on complex processes of negotiation and collaboration. The legal framework stipulates that newly arrived Chinese miners may put their technological capabilities to work only in alliance with Ghanaian nationals. Moreover, up-scaled and more efficient technologies are useless without access to the underground. This access can be secured only through specific alliances with others - with those able to make claims that are persuasively framed in terms of belonging and autochthony.

Crawford and Botchwey also describe other kinds of collaboration. The dominance of the Chinese, they show, is possible only if the military provides security and if state officials are agreeable to accepting bribes. Press reports emphasize that resistance against Chinese dominance in small-scale mining was triggered by the collusion of Ghanaian state authorities of different sorts. ${ }^{1}$ Crawford and Botchwey see the corruption and political collusion that facilitate Chinese dominance as 'old-fashioned politics rather than geopolitics'. For us, the term 'geopolitics' encompasses such processes. The term allows us to foreground the ways in which machine-based access to ore, and political or autochthonous gatekeepers allowing or blocking such access, are effective in conjunction with each other.

This latter point is brought home convincingly in the contribution by Cabada and van Oevelen. Their ethnographic work is situated in Tarkwa, a town with a long history of industrial mining and a mining landscape that is quite different from the two cases described in our article. In Tarkwa, small-scale mining cohabits with its larger-scale industrial counterpart in a context in which the latter has been dominant in the past and the present. The situation they describe is a case of what Crawford and Botchwey identify as the recent scaling up of small-scale mining under Chinese influence. This often takes place in old mining shafts, abandoned by large-scale mining actors as they reorient themselves towards open-pit mining as a consequence of new industrial technologies (in particular, heap leaching with cyanide). In Tarkwa, the insertion of Chinese presence into cohabitation dynamics between different types of miners will indeed change the balance between artisanal and small-scale mining and large-scale mining arrangements. The specific characteristics of these shifts, however, cannot be understood through a focus on old-fashioned politics alone. Instead, geological features that determine how miners working on different scales may encounter one another underground, or may become competitors over the same ore, need to be taken into account. As noted above, the new up-scaled technologies influencing these underground dynamics depend on new alliances between foreigners and nationals (autochthones). Current developments in Tarkwa underscore the need to specify how geological features influence cohabitation arrangements between artisanal and small-scale mining and large-scale mining. In the current scenario - in which the

\footnotetext{
${ }^{1}$ The debate gained momentum when a soldier was murdered by local community members in May 2017. While some reports claim that he was killed because people mistakenly took him to be an armed robber, a variety of other reports relate the murder to galamsey mining, claiming that, for example, the officer was deployed to fight illegal mining, or that he was murdered because he was accused of collaborating with the Chinese (see <https://www.ghanaweb.com/GhanaHomePage/ NewsArchive/Biography-Who-was-Captain-Maxwell-Mahama-542742>; <http://citifmonline. com/2017/05/30/diaso-lynching-capt-mahama-was-deployed-to-fight-galamsey-uncle/>; <http:// africatimes.com/2017/05/30/reports-ghanaian-soldier-lynching-tied-to-illegal-galamsey-goldmining/>, all accessed 16 July 2018).
} 
war on galamsey combines with the scaling up of Chinese operations - no distinction is made between alluvial and hard rock artisanal and small-scale mining operations; in the public debate, it is galamsey who are categorically blamed for destroying water bodies. Cabada and van Oevelen's work on Tarkwa shows the importance of distinguishing between artisanal and small-scale mining operations on the basis of their different geological settings. Correspondingly, in a recent visit to Tarkwa by Sabine Luning, galamsey explicitly asked her to voice their concern about the way in which all their mining was being equated with alluvial mining. They claimed that their reworking of old shafts is less damaging to the environment than alluvial techniques. They did, however, acknowledge that their way of accessing ore in old shafts, through new partnerships with the Chinese, might allow them to access ore under the water table and even under the open-pit mines of industrial miners. In this case, up-scaling might well lead to underground competition with large-scale mining and affect cohabitation arrangements between large-scale mining and artisanal and small-scale mining.

Finally, our analysis of in-depth geopolitics and cohabitation might be extended beyond arrangements between different forms of mining and the groups of miners involved, something with which our original article did not concern itself. This corresponds with Crawford and Botchwey's apt observation that collaborative partnerships do not involve miners alone. Within the large concessions of industrial mining companies, other land users will be affected dramatically, precisely because gold-mining companies hardly ever categorically forbid access to their entire concession. In order to give more attention to other actors, including farmers, and to explore their land-based encounters with large-scale mining or artisanal and small-scale mining actors, a subtle perspective on concessions is required. Such a perspective promotes the study of the discrepancies between maps and formal agreements, which may present an image of closed concessions, and their translation on the ground that includes numerous other activities and local 'interruptions' (Emel et al. 2011). In this approach, concessions are seen as heterogeneous spaces. They comprise securitized access points to underground mining spaces (cf. Bridge 2009) and areas exclusively dominated by the mining company, on the one hand, and other spaces where there is room for agriculture, CSR (corporate social responsibility) projects, trade or other forms of mining, on the other (see also Luning forthcoming; Pijpers forthcoming). The ways in which these forms of cohabitation come about are not necessarily signs of corporate goodwill or companies' local economic development initiatives, but the outcomes of (sometimes tense) negotiation processes between different actors and activities. These, as Ntewusu frames it, are all 'deeply woven into many aspects of Ghana's current reality'. In this situation, new developments, such as further 'wars on galamsey', increased (international) mobility and the introduction of up-scaled technologies, will require new negotiations and shifting alliances in order to access the underground. As this debate section has shown, the concept of indepth geopolitics and a focus on cohabitation, alongside other insights and perspectives, are fruitful analytical approaches to study these negotiation processes and the reconfiguration of alliances that come about in order to access the mineral wealth underground. 


\section{References}

Bridge, G. (2009) 'The hole world: spaces and scales of extraction', New Geographies 2: 43-8.

Ceuppens, B. and P. Geschiere (2005) 'Autochthony: local or global? New modes in the struggle over citizenship and belonging in Africa and Europe', Annual Review of Anthropology 34: 385-408.

D'Angelo, L. and R. J. Pijpers (2018) 'Mining temporalities: an overview', The Extractive Industries and Society 5 (2): 215-22.

Emel, J., M. T. Huber and M. H. Makene (2011) 'Extracting sovereignty: capital, territory, and gold mining in Tanzania', Political Geography 30: 70-9.

Eriksen, T. H. (2005) 'Economies of ethnicity' in J. G. Carrier (ed.), A Handbook of Economic Anthropology. Cheltenham and Northampton: Edward Elgar.

Eriksen, T. H. and E. Schober (2016) 'Introduction: the art of belonging to an overheated world' in T. H. Eriksen and E. Schober (eds), Identity Destabilised: living in an overheated world. London: Pluto Press.

Geenen, S. (2016) 'Hybrid governance in mining concessions in Ghana'. IOB Working Paper 2016.05. Antwerp: Institute of Development Policy and Management, University of Antwerp.

Geschiere, P. (2009) The Perils of Belonging: autochthony, citizenship, and exclusion in Africa and Europe. Chicago IL: Chicago University Press.

Geschiere, P. and F. Nyamnjoh (2000) 'Capitalism and autochthony: the seesaw of mobility and belonging', Public Culture 12 (2): 423-52.

Hardin, R. (2011) 'Concessionary politics: property, patronage, and political rivalry in Central African forest management', Current Anthropology 52 (3): S113-S125.

Lanzano, C. (2018) 'Gold digging and the politics of time: changing timescapes of artisanal mining in West Africa', The Extractive Industries and Society 5 (2): 253-9.

Luning, S. (2018) 'Mining temporalities: future perspectives', The Extractive Industries and Society 5 (2): 281-6.

Luning, S. (forthcoming) 'Characteristics of mining projects: shifting values in negotiations over access to land and water in Burkina Faso'. Submitted to Journal of Rural Studies.

Luning, S. and R. J. Pijpers (2017) 'Governing access to gold in Ghana: in-depth geopolitics on mining concessions', Africa 87 (4): 758-79.

Pijpers, R. J. (2018) 'Navigating uncertainty: large-scale mining and micro-politics in Sierra Leone'. PhD thesis, University of Oslo.

Pijpers, R. J. (forthcoming) 'Territories of contestation: negotiating mining concessions through encounters' in R. J. Pijpers and T. H. Eriksen (eds), Mining Encounters: extractive industries in an overheated world. London: Pluto Press. 